\title{
MILK YIELD, MILK COMPOSTION AND SOME BLOOD METABOLITES OF LACTATING BUFFALOES FED RATONS CONTAINING SORGHUM AND MAIZE SILAGE OR ALFALFA FORAGE \\ Abd-El-Moty, E. K. I. ${ }^{1}$;G. M.Solouma ${ }^{2}$; E. B. Soliman ${ }^{1}$ and A.M. Saleem ${ }^{3}$ \\ 1 Anim. Prod. Dep., Fac. of Agric. El-Minia Univ. El-Minia, Egypt. \\ 2 Anim. Prod. Dep. Fac. of Agric. Sohag Univ. Sohag, Egypt. \\ 3 Anim. Prod. Dep. Fac. of Agric.. South Valley Univ. Qena, Egypt.
}

\begin{abstract}
The present study was carried out at the Experimental Farm of Animal Production Department, Faculty of Agriculture, South Valley University, Qena. Six lactating buffaloes averaged $600 \pm 15 \mathrm{~kg}$ live body weight at their $3 \mathrm{rd}$ to 5 th lactation season and after reaching the peak of milk production were used in this study. The aims of this study were to investigate the performance of lactating buffaloes as affected by feeding maize and sorghum silage in comparison with those fed fresh alfalfa on milk yield, composition and some blood constituents The experimental design that used was switch back design in three periods of one month each. The first 23 days of each period were for diets adaptation, while the last 7 days were for data and samples collection. Animals were individually fed on the following experimental treatments. The first treatment (T1) contained $48.0 \%$ concentrate feed mixture (CFM), $24.0 \%$ fresh alfalfa and $28.0 \%$ rice straw. The second treatment (T2) contained $48.0 \%$ concentrate mixture, $38.0 \%$ maize silage and $14.0 \%$ rice straw, while the third treatment ( T3) contained $46.0 \%$ concentrate feed mixture, $40.0 \%$ sorghum silage and $14.0 \%$ rice straw. The feed efficiency was calculated as $\mathrm{kg} 7 \%$ fat corrected milk (FCM) / kg total dry matter intake (TDMI). Profit (L.E) above feeding cost was calculated. The results revealed that there is a significant difference $(P<0.05)$ in the nutritive value in term of TDN and DCP among the three different treatments. The nutritive values (\%) were $58.25,65.55$ and 63.61 for TDN and $7.01,6.09$ and 5.80 for DCP in T1, T2 and T3, respectively. Average total daily DM intake / buffalo (TDMI) was insignificantly different among treatments. Average daily milk yield and $7 \%$ fat corrected milk $(7 \% \mathrm{FCM})$ were significantly $(p<0.05)$ higher in T2 and T3 as compared to $\mathrm{T} 1$. The efficiency of $7 \% \mathrm{FCM}$ production per $\mathrm{kg}$ TDMI was significantly increased $(p<0.05)$ by $14.43 \%$ for buffaloes fed T2 and T3 compared to buffaloes T1. The profit above total costs were 7.88, 11.09 and 13.06 L.E /h/day for T1, T2 and T3, respectively. Moreover, the results showed that there was a significant difference among the experimental treatments in some blood components (glucose, total protein, total lipids, triiodothyronine and thyroxin). There were insignificant difference among treatments in serum albumin, globulin, and cholesterol concentrations. The average concentration of glucose, total lipids and thyroid hormone was lower $(P<0.05)$ in $\mathrm{T} 1$ as compared to T2 and T3, while the opposite trend was observed in total protein. It could be concluded that preserving amount of maize and sorghum plants as silage can be successfully used for feeding ruminants without any adverse effect on productive performance and physiological responses. Therefore, offering facilities are need to make silage from fresh corn and sorghum plants to the farmers is very important and will help to apply this technology and encourage the farmers to use these products for feeding to reduce feed cost and save considerable of expensive concentrates silage specially in summer for lactating buffaloes. epically under upper Egypt conditions.
\end{abstract}

Keywords: milk yield, lactating buffaloes, sorghum and maize, Blood metabolites, silage 


\section{INTRODUCTION}

The shortage of animal feedstuffs represents a real problem limiting the development of animal production in Egypt. Alfalfa forage (Medicago sativa) is a major dietary component for lactating animals which is called king of forages. An important objective of livestock feeding in most developing countries is to improve the use of potentially available forage to maximize the turn home grown feeds.

In Egypt total planted areas of corn (Zea maize $L$ ) crop was about 2 million feddans and sorghum (sorghum bicolor (L) moench) crop was about 400.000 feddans (Agriculture Statistics, Egypt, 2003). The high energy content and cheap price of maize and sorghum silage may promote the breeders to use maize and sorghum silage for feeding ruminants. Silage requires three times less storage space per unit of DM compared with dry forage. There is less wastage of feed when silage is fed compared with feeding dry feedstuffs and the feeding process lands itself to automation (Perry and Cecava., 1995). Forage sorghum can produce silage that has a similar yield of digestible DM as does tropical corn silage when harvested at an optimal stage of maturity (Black et al., 1980).

Therefore, the aim of this study were to investigate the productive performance of lactating buffaloes as affected by feeding maize and sorghum silage in comparison with those fed fresh alfalfa. Milk yield, Milk composition and some blood metabolites were also studied.

\section{MATERIALS AND METHODS}

The present study was carried out at the Experimental Farm of Animal Production Department, Faculty of Agriculture, South Valley University, Qena. Experimental design:

Six lactating buffaloes, averaged $600 \pm 15 \mathrm{~kg}$ live body weight (LBW) at their $3^{\text {rd }}$ to $5^{\text {th }}$ lactation season were used on this study, after reaching the peak of milk production. The experimental design used was switch back design (Lucas 1956) in three periods each of one month. The first 23 days of each period were for diets adaptation, and the last 7 days were for data and samples collection. It is often desirable to take advantage of the sensitivity of switch -back trials when dairy research with dairy cattle was used.

As was noted, the design and the method of analysis automatically removed experimental error between buffalo variation in production level and most of variation in persistency.

\section{Feeding and management:}

Tow types of silages were made in two trench silo, one was whole plant maize and the other was whole plant sorghum, the plants were harvested at same time, silo opened after three months. Animals were individually fed according to NRC (1988) recommendation. Buffaloes were fed the following experimental rations. T1: contained $48 \%$ concentrate feed mixture (CFM), 24\% fresh alfalfa and $28 \%$ rice straw (RS). T2: contained $48 \%$ CFM, $38 \%$ maize silage (MS) and $14 \%$ RS. T3: contained $46 \%$ CFM, $40 \%$ sorghum silage (SS) and 14\% RS. The CFM used contained: $40 \%$ 
yellow corn, $14 \%$ wheat bran, $15 \%$ linseed meal, $13.5 \%$ soybean meal, $15 \%$ molasses, $1 \%$ calcium carbonate, $1 \%$ sodium chloride and $0.5 \%$ mineral plus vitamins additives. Daily amounts of feed were weighed and offered individually to the animals. Residuals were weighed daily then actual feed intake for each buffalo was calculated. Feed efficiency was calculated as $\mathrm{kg}$ $7 \% \mathrm{FCM} / \mathrm{kg}$ total dry matter intake (TDMI) . Profit above feeding cost (L.E) was calculated by the difference between total daily cost (L.E) and price of daily milk yield (L.E).

Lactating buffaloes were milked twice daily at 4 am and $5 \mathrm{pm}$ and fed at 9 am and $6 \mathrm{pm}$. Alfalfa were cut in the morning and fed fresh to buffaloes, in the control group (T1) twice daily (at $9.0 \mathrm{am}$ and $6.0 \mathrm{pm}$ ). Maize and sorghum silage were offered in T2 and T3, respectively. The CFM was fed to animal groups before offering alfalfa, maize and sorghum silage. Rice straw was offered twice daily after feeding the previous ingredients. Fresh water was available all the day time.

Samples of alfalfa, maize silage and sorghum silage, CFM, rice straw and feces were dried until reached a constant weight in air-oven for dry matter (DM) determination. Proximate analysis of the experimental samples was carried out according to A.O.A.C. (1990) procedures. The nitrogen free extract (NFE) was calculated by difference. Daily milk samples for morning and evening milking of the same day for each buffalo were collected on the last week of each period and mixed together then analyzed individually for fat, protein , total solids and solid not fat using Milkoscan apparatus (Model $133 \mathrm{~B})$.

Daily milk yield was recorded and $7 \%$ fat corrected milk (7\% FCM) produced form each buffalo was calculated using the formula given by Raafat and Saleh (1962) as follows: $7 \% \mathrm{FCM}=0.265$ milk yield +10.5 fat yield.

At the last week of each period $10 \mathrm{ml}$ blood samples were collected in heparinized tubes from the jugular vein before morning feeding. Blood samples were centrifuged immediately at $3000 \mathrm{rpm}$ for $15 \mathrm{~min}$ and serum was stored at $-20^{\circ} \mathrm{C}$ until analysis using commercial kits. Obtained blood serum samples were used to determine total protein and albumin as described by Doumas (1971) and Kaplan and Szalbo (1983), while serum globulin was obtained by the difference between the total protein and albumin concentrations. Albumin / globulin ratio was then calculated. Total lipids and cholesterol content were determined according to Schalm et al. (1975). Glucose in blood serum was also determined according to Trinder (1969). Serum triiodothyronine and thyroxin concentrations were determined by a direct phase-solids $\mathrm{I}^{125}$ radioimmunoassay technique using coat-A-count TKT3 and TKT4 according to Irvin and Standever (1968) and Chopra et al. (1971). The RIA kits were purchased from Diagnostic Products Corporation (CPC, Los Angeles, CA, 90045-5597, USA).

Digestibility trials:

Fecal samples were collected twice daily at $7.0 \mathrm{am}$ and $2.0 \mathrm{pm}$ at the last week of each experimental period directly from the rectum of each buffalo and were kept frozen. Fecal samples were dried at $70^{\circ} \mathrm{C}$ in air-oven for constant weight and were ground through $1 \mathrm{~mm}$ mill screen and mixed 
together, then analyzed for DM, OM, CP, CF EE and NFE. Digestibility coefficients of chemical nutrients were determined using acid insoluble ash (AIA \%) as natural marker according to Van Keulen and Young (1977).

Statistical analysis:

The first step of statistical analysis was to compute the $D$ value for each experimental buffaloes according to Brandt (1938). The mathematical equation was as the following: $D=Y_{1}-2 Y_{2}+Y_{3}$. Which, $Y_{1}, Y_{2}$ and $Y_{3}$ represent the performance in period 1,2 , and 3 respectively .

The second step was computing $M=$ sum of D's for all buffaloes in all sequences. The third step was computing $Q$ for each treatment, in which $Q=$ sum of the D's for the buffaloes receiving the specific treatment in the first and third period minus the sum of the D's for the buffaloes receiving the same treatment in the second period. Computation for analysis of variance of the $\mathrm{D}$ value was done according to Lucas (1956). The degree of freedom and computation formulas for the sum of squares required in the analysis of variance are shown in Table (1).

Table (1) : Computation for analysis of variance of the $D$ values

\begin{tabular}{|c|c|c|c|}
\hline \multirow{2}{*}{ Source of variance } & \multirow{2}{*}{ Degree of freedom } & \multicolumn{2}{|c|}{ Sum of squares } \\
\cline { 3 - 4 } Correction factor & 1 & $C F$ & $\left\{M^{2} / 3 n p(p-1)\right\}$ \\
\hline Total(corrected) & $\{n p(p-1) / 2\}-1$ & $T S S$ & $1 / 6 \sum_{i} \sum D_{i j}{ }^{2}-C F$ \\
\hline Treatment & $p-1$ & $S S T$ & $1 / 6 n p\left(\sum_{k} Q_{k}^{2}\right)$ \\
\hline Error & $\left\{n p^{2}-(n+2) p / 2\right\}$ & $S S E$ & $T S S-S S T$ \\
\hline
\end{tabular}

a The divisor 6 is used to replace the sums of squares per buffalo per period basis. The parameters used the computation formulas are defined as follow:

$P=$ The number of treatments $; n=2 r$, where $r=$ The number of buffaloes per treatment sequence.

$D_{i j}=$ The $D$ value for the $j^{\text {th }}$ buffaloes on $i^{\text {th }}$ treatment sequence .

$Q_{k}=$ The $Q$ value for the $k^{\text {th }}$ treatment.

Duncan's Multiple Range Test (Duncan, 1955) was used to test the significance differences among treatment means using SAS (1996) program. The same statistical analysis system was used for all physiological parameters.

\section{RESULTS AND DISCUSSION}

\section{1- Nutritional evaluation of the experimental rations :}

Values of the chemical composition of the tested ingredients (Table 2), experimental rations (Table 3 ) and the effect of feeding different silage rations in comparison with alfalfa one on the digestion coefficient of nutrients (Table 4). It is of interest to note that most of chemical nutrients of the three rations were practically similar, except that of $\mathrm{CP} \%$, since it was higher in control ration (12.14\%) than those of T2 (10.51\%) and T3 $(9.90 \%)$. 
Table (2): Proximate analysis of the experimental feedstuffs

\begin{tabular}{|l|c|c|c|c|c|c|c|}
\hline \multirow{2}{*}{ Items } & \multirow{2}{*}{ DM } & \multicolumn{6}{c|}{ On dry matter basis \% } \\
\cline { 3 - 8 } & & OM & CP & EE & CF & NFE & Ash \\
\hline Alfalfa & 21.08 & 89.59 & 18.57 & 1.55 & 25.26 & 44.21 & 10.41 \\
\hline Maize silage (MS) & 24.94 & 93.53 & 8.70 & 1.37 & 35.32 & 48.14 & 6.47 \\
\hline Sorghum silage (SS) & 28.09 & 90.95 & 7.48 & 1.68 & 33.88 & 47.91 & 9.05 \\
\hline Concentrate feed mixture (CFM) & 89.57 & 94.03 & 13.89 & 3.37 & 13.87 & 62.90 & 5.97 \\
\hline Rice straw (RS) & 93.13 & 84.12 & 3.57 & 1.70 & 32.93 & 45.92 & 15.88 \\
\hline
\end{tabular}

Table (3): Proximate analysis of experimental rations

\begin{tabular}{|l|c|c|c|c|c|c|c|}
\hline \multirow{2}{*}{ Treatments } & \multirow{2}{*}{ DM } & \multicolumn{7}{|c|}{ On dry matter basis \% } \\
\cline { 3 - 8 } & & OM & CP & EE & CF & NFE & Ash \\
\hline T1 & 74.06 & 90.20 & 12.14 & 2.46 & 22.00 & 53.60 & 9.80 \\
\hline T2 & 65.48 & 92.46 & 10.48 & 2.37 & 24.73 & 54.88 & 7.54 \\
\hline T3 & 64.92 & 91.44 & 9.89 & 2.45 & 24.63 & 54.47 & 8.56 \\
\hline
\end{tabular}

Concerning the feeding values of tested rations, the results in Table( 4) showed that the values of TDN were increased significantly $(P<0.05)$ by 12.5 and $9.2 \%$ for lactating buffaloes fed silage rations (T2 and T3) compared to those fed control ration (T1). These differences reflect the higher digestibility of nutrients of silage rations than control ration. The high TDN values of the rations contained CFM and silage may be attributed to the mutual associative effects of silage with concentrate mixture (Mohamed et al., 1999 and Gafaar, 2001).

Table (4): Average digestion coefficients and nutritive values of tested rations

\begin{tabular}{|l|c|c|c|c|c|}
\hline \multirow{2}{*}{ Nutrition } & \multicolumn{3}{|c|}{ Treatments } & \multirow{2}{*}{ SE } & \multirow{2}{*}{ Sig } \\
\cline { 2 - 5 } & T1 & T2 & T3 & & \\
\hline Digestion coefficients, \% & & & & & \\
\hline DM & $62.46^{\mathrm{b}}$ & $66.70^{\mathrm{a}}$ & $66.25^{\mathrm{a}}$ & 0.81 & ${ }^{*}$ \\
\hline OM & 61.60 & 65.35 & 65.30 & 2.91 & $\mathrm{NS}$ \\
\hline CP & 57.77 & 58.11 & 58.62 & 1.69 & $\mathrm{NS}$ \\
\hline EE & $71.58^{\mathrm{b}}$ & $77.20^{\mathrm{a}}$ & $72.12^{\mathrm{a}}$ & 1.22 & ${ }^{*}$ \\
\hline CF & $50.62^{\mathrm{b}}$ & $60.84^{\mathrm{a}}$ & $59.41^{\mathrm{a}}$ & 1.73 & ${ }^{*}$ \\
\hline NFE & $67.43^{\mathrm{b}}$ & $73.42^{\mathrm{a}}$ & $71.69^{\mathrm{a}}$ & 1.68 & ${ }^{*}$ \\
\hline Nutritive value, \% & & & & & \\
\hline TDN & $58.25^{\mathrm{b}}$ & $65.55^{\mathrm{a}}$ & $63.61^{\mathrm{a}}$ & 2.46 & ${ }^{*}$ \\
\hline DCP & $7.01^{\mathrm{a}}$ & $6.09^{\mathrm{b}}$ & $5.80^{\mathrm{b}}$ & 0.43 & ${ }^{*}$ \\
\hline
\end{tabular}

a and $b$ Means in the same row followed by different superscripts are significantly different $\left({ }^{*} \mathrm{p}<0.05\right) . \mathrm{NS}=$ not significant

However, the DCP for control ration was significantly $(p<0.05)$ higher than those of MS (T2) and SS (T3) rations (Table 4). The differences in DCP among the rations may be attributed to the variations in CP contents (Table 2 ) and CP digestibility (Table 4) for the three rations. No significant difference was found in TDN and DCP between rations T2 and T3. These results are in 
harmony with those obtained by Lopez-Guisa et al. (1991) ; Chauhan (1995) and Mohamed et al. (1998). In another study, Mohamed et al. (1999) reported that increasing proportion of maize silage in the ration to $25 \%$ and $50 \%$ of dry matter intake tended to increase TDN, while DCP decreased compared with control ration (berseem). Also, Nichols et al.(1998) indicated that sorghum silage has equal or slightly greater nutritional value than tropical corn silage when these forages were fed at equal concentrations of dietary fiber.

\section{2- Effect of feeding experimental rations on productive performance:}

\section{2-1- Feed intake}

Average daily dry matter intake (DMI) and feed intake for lactating buffaloes fed different experimental rations are presented in Table (5).

Daily DMI of maize silage (T2) and sorghum silage (T3) was higher by 57.91 and $77.48 \%$ compared to that of alfalfa (T1). Daily DMI of concentrates mixture was fixed in all treatments. While, daily DMI for rice straw was significantly $(p<0.05)$ different between treatments. Generally, insignificant differences in total dry matter intake (TDMI) were found between lactating buffaloes fed T1, T2 and T3. These results are in agreement with those obtained by Dhiman and Satter (1997) who noticed that DMI was similar for lactation cows fed alfalfa silage, one-third corn silage and two-third corn silage diets.

Table (5) : Average daily dry mater intake on dry matter basis of lactating buffaloes fed different experimental rations

\begin{tabular}{|l|c|c|c|c|}
\hline \multirow{2}{*}{ Items } & \multicolumn{3}{c|}{ Treatments } & \multirow{2}{*}{ Sig. } \\
\cline { 2 - 5 } & T1 & T2 & T3 & \\
\hline Average. body weight, kg DMI / head / day, kg & 606.67 & 617.00 & 592.17 & NS \\
& & & & \\
\hline 1) Alfalfa & 3.16 & - & - & - \\
\hline 2) Maize silage & - & 4.99 & - & - \\
\hline 3) Sorghum silage & - & - & 5.62 & - \\
\hline 4) Concentrate mixture & 6.27 & 6.27 & 6.27 & Ns \\
\hline 5) Rice straw & $3.72^{\mathrm{a}}$ & $1.86^{\mathrm{b}}$ & $1.86^{\mathrm{b}}$ & ${ }^{*}$ \\
\hline 6) TDMI kg/h/d & 13.16 & 13.12 & 13.75 & $\mathrm{Ns}$ \\
\hline 7) TDNI kg/h/d & $7.67^{\mathrm{b}}$ & $8.60^{\mathrm{a}}$ & $8.75^{\mathrm{a}}$ & ${ }^{*}$ \\
\hline 8) $\mathrm{DCPI} \mathrm{g/h/d}$ & $923^{\mathrm{a}}$ & $799^{\mathrm{b}}$ & $898^{\mathrm{b}}$ & ${ }^{*}$ \\
\hline
\end{tabular}

a, and b Means in the same row followed by different superscripts are significantly different $\left({ }^{*} \mathrm{p}<0.05\right)$. NS = not significant

1) $3.16 \mathrm{~kg}$ alfalfa $\mathrm{DM}=15.0 \mathrm{~kg}$ fresh alfalfa.

2) $4.99 \mathrm{~kg}$ maize silage $D M=20.0 \mathrm{~kg}$ fresh maize silage.

3) $5.62 \mathrm{~kg}$ sorghum silage $\mathrm{DM}=20.0 \mathrm{~kg}$ fresh sorghum silage.

4) $6.27 \mathrm{~kg}$ concentrate mixture $\mathrm{DM}=7.0 \mathrm{~kg}$ fresh concentrate mixture.

5) $3.72 \mathrm{~kg}$ rice straw $D M=4.0 \mathrm{~kg}$ fresh rice straw.

$1.86 \mathrm{~kg}$ rice straw $\mathrm{DM}=2.0 \mathrm{~kg}$ fresh rice straw.

6) $\mathrm{TDMI}=$ total dry matter intake.

7) $\mathrm{TDNI}=$ total digestible nutrients intake.

8) $\mathrm{DCPI}=$ digestible crude protein intake.

Also, Elready (2000) reported similarty TDMI between lactating cows fed control ration (concentrate mixture, fresh berseem and rice straw) and those fed rations contained different levels of corn Stover silage or corn silage. 


\section{2-2- Milk yield (kg/day):}

Average actual daily milk yield and average daily $7 \%$ fat corrected milk (7\%FCM) of lactating buffaloes fed different experimental rations are shown in Table (6) .

The present results revealed that lactating buffaloes fed MS (T2) and SS (T3) rations had yielded significantly $(p<0.05)$ higher average actual daily milk yield by 11.81 and $18.18 \%$, respectively, than the control ration (T1). Also, the differences were statistically significant $(p<0.05)$ when average milk yield was adjusted to $7 \%$ FCM. In this respect, Mahmoud et al. (1992), Elready (2000) and El-Ashry et al (2003) reported that inclusion of maize silage in the ration of lactating Friesian or buffaloes improved average actual daily milk yield and FCM.

These results indicated that the requirements of the expected milk production of buffaloes were covered by TDN of T2 and T3 rations. Similar results were obtained by Mohamed et al. (1998) who indicated that significantly $(p<0.05)$ higher milk yield and $7 \%$ FCM were obtained when buffaloes were fed whole plant maize silage in comparison with those fed berseem. In spite of the highest value of DCP of T1 compared to that of T2 and T3, there was no improvement in actual milk yield or $7 \%$ FCM. This means that animals fed alfalfa had covered over the requirements of protein. El-Aidy (2003) indicated that feeding berseem usually covered $96 \%$ of energy and $177 \%$ of protein requirement of animals.

No significant differences were found in actual milk yield and $7 \%$ FCM between buffaloes fed ration T2 and T3. These results are in agreement with those obtained by Dijk et al. (1985). Also, Nichols et al. (1998) indicated that milk production was not affected by feeding tropical corn silage and sorghum silage as a basal forage in the diet for high producing cows.

\section{2-3- Milk composition:}

Milk fat percentage was increased by 2.69 and $1.21 \%$ for buffaloes fed silage rations T2 and T3, respectively compared to those fed T1. But insignificant differences were existed among treatments. The presents result was in agreement with that obtained by Mahmoud et al. (1992), who recorded that slight variation in milk fat was obtained when maize silage and fresh berseem were included in the ration of lactating Friesian cows. In addition, Nichols et al. (1998) reported that milk fat percentage was not statistically influenced by feeding tropical corn silage and sorghum silage for high producing cows. Also, Elready (2000) reported that a slight increase in fat percentage was obtained when Freisian cows were fed rations containing different levels of corn silage compared with those fed control ration (fresh berseem).

As shown in Table (6), milk fat yield ( $\mathrm{kg} / \mathrm{day}$ ) was significantly $(p<0.05)$ increased by 15.79 and $19.30 \%$ for buffaloes fed T2 and T3 in comparison with those fed T1. These results are in a harmony with those reported by Mohamed et al. (1998). The significant increase in milk fat yield in T2 and T3 compared to T1 may be due to higher milk yield rather than fat percentage in milk. 
Abd-El-Moty, E. K. I. et al.

Table (6): Milk yield and composition of lactating buffaloes fed different experimental rations

\begin{tabular}{|l|c|c|c|c|c|}
\hline \multirow{2}{*}{\multicolumn{1}{|c|}{ Items }} & \multicolumn{3}{|c|}{ Treatments } & \multirow{2}{*}{ S.E. } & \multirow{2}{*}{ Sig. } \\
\cline { 2 - 5 } & T1 & T2 & T3 & & \\
\hline Milk production (kg/day) & & & & & \\
\hline Actual milk yield (kg/day) & $7.70^{\mathrm{b}}$ & $8.61^{\mathrm{a}}$ & $9.10^{\mathrm{a}}$ & 0.397 & ${ }^{*}$ \\
\hline $7 \%$ FCM (kg/day) & $8.03^{\mathrm{b}}$ & $9.16^{\mathrm{a}}$ & $9.59^{\mathrm{a}}$ & 0.297 & ${ }^{*}$ \\
\hline Kg 7\% FCM/kg TDMI & $0.610^{\mathrm{b}}$ & $0.698^{\mathrm{a}}$ & $0.698^{\mathrm{a}}$ & 0.022 & ${ }^{*}$ \\
\hline Milk composition (\%) & & & & & \\
\hline Fat & 7.43 & 7.63 & 7.52 & 0.099 & $\mathrm{NS}$ \\
\hline Protein & 4.31 & 4.29 & 4.28 & 0.066 & $\mathrm{NS}$ \\
\hline SNF & 10.23 & 10.30 & 10.22 & 0.012 & $\mathrm{NS}$ \\
\hline TS & 17.66 & 17.93 & 17.74 & 0.057 & $\mathrm{NS}$ \\
\hline Yield of milk constituents. & & & & & \\
\hline Fat yield (kg/day) & $0.57^{\mathrm{b}}$ & $0.66^{\mathrm{a}}$ & $0.68^{\mathrm{a}}$ & 0.033 & ${ }^{*}$ \\
\hline Protein yield (kg/day) & $0.33^{\mathrm{b}}$ & $0.37^{\mathrm{a}}$ & $0.39^{\mathrm{a}}$ & 0.001 & ${ }^{*}$ \\
\hline
\end{tabular}

a and b Means in the same row followed by different superscripts are significantly different $\left({ }^{*} \mathrm{p}<0.05\right)$. NS = not significant.

$7 \% F C M=0.265$ milk yield + 10.5 fat yield (Raafat and Saleh, 1962).

The results of milk protein percentage and yield are shown in Table (6). It can be noticed that the control ration, which contained alfalfa (T1) recorded $4.31 \%$, while silage rations (T2 and T3) recorded $4.29,4.28 \%$, respectively. Non-significant differences were found among treatments. These results are in agreement with those obtained by Mohamed et al. (1998), who reported that milk protein percentage did not differ when lactating buffaloes were fed rations contained berseem (control ration), corn Stover silage and whole plant corn silage. Also, Elready (2000) reported that a slight variation in milk protein percentage between Frisian cows fed control ration (fresh berseem) and those fed rations contained different levels of maize silage. Similar results were obtained by Thomas et al. (1981) and Valdez et al. (1988). Data in Table (6) revealed that buffaloes fed silage rations (T2 and T3) produced more protein yield $(\mathrm{P}<0.05)$ than those fed the control ration (T1).

The results of total solids (TS) and solids not fat (SNF) percentages are presented in Table (6) . Dietary rations had insignificant effect on TS or SNF percentage in buffalo milk. These results were in accordance with those observed by Dhiman and Satter (1997). They found that SNF percentage did not differ among cows fed alfalfa silage, one-third corn silage and two-third corn silage diets. Similar results were found by Elready (2000), who found that no significant difference in TS and SNF percentages of cows fed control ration (berseem) and those fed rations containing different levels of corn silage.

\section{3- Feed efficiency and economic evaluation:}

Data presented in Table (6) indicated that the calculated efficiency of $7 \%$ FCM production per $\mathrm{kg}$ TDMI was significantly $(\mathrm{p}<0.05)$ increased by $14.43 \%$ for buffaloes fed T2 and T3 compared to buffaloes fed T1. This result is related to differences in actual milk yield and 7\% FCM production 
among treatments. The better feed efficiency in silage rations (T2 and T3) compared to the control ration (T1) may be attributed generally to the high digestibility for all nutrients in T2 and T3 (Table 4). These results were in agreement with those obtained by Elready (2000) who reported that the better efficiency ( $\mathrm{kg} 4 \% \mathrm{FCM} / \mathrm{kg} \mathrm{DMI}$ ) was recorded for rations containing different levels of corn Stover silage or corn silage with concentrate mixture in comparison with ration containing berseem with concentrate mixture. No significant difference in efficiency of $7 \%$ FCM production was observed between T2 and T3. This is may be due to insignificant differences in nutrient digestibility coefficients or in TDN and DCP values between rations T2 and T3 (Table 4). Those results are in agreement with these obtained by El-Ashry et al. (2003).

Data of economic evaluation in Table (7) revealed that the profits above total cost were 7.88, 11.09 and $13.06 \mathrm{LE}$. /h/day for T1, T2 and T3, respectively. From economic evaluation, lactating buffaloes fed silage rations (T2 or T3) increased daily return. Then it had the best economic efficiency of milk production in comparison with those fed control ration (T1). This is due to increased of milk yield and decreased daily feed cost. The present results are fall in the line with those obtained by several investigators e.g., Mahmoud et al. (1992), El-Sayes et al. (1997) Khinizy et al. (1997) and Mohamed et al. (1999). They found that using maize silage for feeding of dairy cattle or fattening of calves improved their performance and reduced feed cost.

Table (7): Economic evaluation of different experimental rations used for feeding lactating buffaloes

\begin{tabular}{|l|c|c|c|}
\hline \multicolumn{1}{|c|}{ Items } & \multicolumn{3}{c|}{ Treatments } \\
\cline { 2 - 4 } & TI & T2 & T3 \\
\hline Milk yield (kg/day) & 6.74 & 8.61 & 9.10 \\
\hline Daily feeding cost (LE.) & 13.72 & 13.24 & 12.74 \\
\hline Vet. and mange. cost (LE.) ${ }^{\star *}$ & 1.50 & 1.50 & 1.50 \\
\hline Total daily cost (L.E.) & 15.22 & 14.74 & 14.24 \\
\hline Price of daily milk yield (LE.)*** & 23.10 & 25.83 & 27.30 \\
\hline Profit above total cost (LE.) & 7.88 & 11.09 & 13.06 \\
\hline
\end{tabular}

${ }^{*}$ Daily feed cost $=$ Total cost of fresh amount of different feedstuffs .

The feedstuffs prices (L.E./ton) for fresh alfalfa, maize silage, sorghum silage, rice straw and concentrate mixture were $213,154,129,180$ and 1400 , respectively, based on the common prices in 2006 in Qena Governorate.

${ }^{\star \star}$ Veterinary and management cost $=1.50 \mathrm{LE} / \mathrm{h} / \mathrm{day} .{ }^{\star \star \star}$ Price $1 \mathrm{~kg}$ milk yield= $3 \mathrm{LE}$.

\section{4- Some blood serum metabolites of lactating buffaloes:}

Serum glucose concentrations $(\mathrm{mg} / 100 \mathrm{ml})$ of different experimental rations are presented in Table (8). The results indicated that the highest glucose concentration was obtained by buffaloes fed MS ration (T2) followed by those fed SS ration (T3) compared to those fed control ration (T1). Glucose level was significantly $(p<0.05)$ increased by 16.72 and $14.98 \%$ for buffaloes fed silage rations (T2 and T3), respectively, compared with those fed the control ration $(\mathrm{T} 1)$. No significant differences were found between buffaloes fed rations T2 and T3. Increasing of glucose levels in blood serum 
of lactating buffaloes fed treatments T2 and T3 compared to T1 could be due to increasing TDN value in rations T2 and T3 above T1 (Table 4). Ahmed (2003) studied the effect of energy and protein allowance in ration for pregnant and milk producing buffaloes. He indicated there was close relationship between energy in diets and glucose level in blood. The present results were in agreement with those obtained by Glen (1985), who found that glucose in plasma was slightly higher when feeding corn silage versus alfalfa forage. Also, Graf et al. (2005) noticed that supplementing corn silage to the diets of grazing dairy cows increased blood glucose levels compared with cows fed grass alone.

Table (8): Levels of some blood serum metabolites of lactating buffaloes as affected by feeding different experimental rations

\begin{tabular}{|l|c|c|c|c|c|}
\hline \multirow{2}{*}{ Items } & \multicolumn{3}{|c|}{ Treatments } & \multirow{2}{*}{ SE } & \multirow{2}{*}{ Sig. } \\
\cline { 2 - 6 } & T1 & T2 & T3 & & ${ }^{*}$ \\
\hline Glucose $(\mathrm{mg} / 100 \mathrm{ml})$ & $60.69^{\mathrm{b}}$ & $70.84^{\mathrm{a}}$ & $69.78^{\mathrm{a}}$ & 0.89 & ${ }^{*}$ \\
\hline Total protein $(\mathrm{g} / 100 \mathrm{ml})$ & $8.27^{\mathrm{a}}$ & $7.61^{\mathrm{b}}$ & $7.40^{\mathrm{b}}$ & 0.12 & ${ }^{*}$ \\
\hline Albumin $(\mathrm{g} / 100 \mathrm{ml})$ & 4.72 & 4.47 & 4.41 & 0.14 & $\mathrm{NS}$ \\
\hline Globulin $(\mathrm{g} / 100 \mathrm{ml})$ & 3.55 & 3.14 & 3.00 & 0.24 & $\mathrm{NS}$ \\
\hline A/G ratio & 1.33 & 1.42 & 1.47 & 0.14 & $\mathrm{NS}$ \\
\hline Total lipids $(\mathrm{mg} / 100 \mathrm{ml})$ & $4.09^{\mathrm{b}}$ & $4.54^{\mathrm{a}}$ & $4.71^{\mathrm{a}}$ & 0.11 & ${ }^{*}$ \\
\hline Cholesterol $(\mathrm{mg} / 100 \mathrm{ml})$ & 129.93 & 131.47 & 133.10 & 4.44 & $\mathrm{NS}$ \\
\hline Triiodothyronine $(\mathrm{ng} / \mathrm{dl})$ & $113.11^{\mathrm{b}}$ & $128.53^{\mathrm{a}}$ & $126.28^{\mathrm{a}}$ & 1.31 & ${ }^{*}$ \\
\hline Thyroxin $(\mu \mathrm{g} / \mathrm{dl})$ & $2.36^{\mathrm{b}}$ & $2.89^{\mathrm{a}}$ & $2.80^{\mathrm{a}}$ & 0.05 & $*$ \\
\hline a and b means in the same row followed by different superscipts are significantly different
\end{tabular}

$\mathrm{a}$ and $\mathrm{b}$ means in the same row followed by different superscripts are significantly differen $\left({ }^{*} \mathrm{p}<0.05\right) . \mathrm{NS}=$ not significant

T1: contained $48.0 \%$ concentrate mixture $(\mathrm{CM})+\mathbf{2 4 . 0} \%$ alfalfa $+\mathbf{2 8 . 0} \%$ rice straw (RS)

T2: contained $48.0 \%$ concentrate mixture $(\mathrm{CM})+38.0 \%$ maize silage $(\mathrm{MS})+14.0 \%$ rice straw (RS)

T3: contained $46.0 \%$ concentrate mixture $(\mathrm{CM})+\mathbf{4 0 . 0} \%$ sorghum silage $(\mathrm{SS})+\mathbf{1 4 . 0} \%$ rice straw

Generally, the plasma protein profile of a normal healthy animal is relatively constant and generally controlled. However, nutritional inadequacies can lead to a marked decrease in plasma protein (Baker, 1995). Concentrations of serum total protein and protein fractions $(\mathrm{g} / 100 \mathrm{ml})$ of lactating buffaloes fed the experimental rations are summarized in Table (8). These results indicated that lactating buffaloes fed alfalfa ration had the higher $(p<0.05)$ concentration of total protein than those fed MS ration and SS ration. This significant positive effect was probably due to the higher level of CP $(12.14 \%)$ in the alfalfa ration than the silage rations (Table 3$)$. This is in accordance with the conclusion of Kumar et al. (1980) who reported that there is a positive correlation between dietary protein and plasma protein concentration. Similar results were reported by Elready (2000) who noticed that cows fed control ration (fresh berseem) had the highest protein concentration but the lowest concentration was recorded in cows fed corn silage. The present results revealed that there were insignificant difference 
between T2 and T3 on the concentration of serum protein due to feeding MS and SS rations.

The highest albumin value was obtained with buffaloes fed alfalfa ration, while those fed silage rations had the lowest values. However, the differences were statistically not significant. Also, the result indicated that globulin value was $3.55 \mathrm{~g} / 100 \mathrm{ml}$ for buffaloes fed alfalfa ration $\mathrm{T} 1$, while those fed silage rations had lower values being 3.14 and $3.00 \mathrm{~g} / 100 \mathrm{ml}$ for T2 and T3, respectively. However, the differences were not statistically significant.

These results were in a harmony with those obtained by Elready (2000), who indicated that cows fed control ration (fresh berseem) had the highest albumin concentration but the lowest concentration was recorded in cows fed corn silage. The data of albumin / globulin (A/G) ratio of lactating buffaloes indicated that the mean values of $A / G$ ratio for control, MS and SS rations were $1.33,1.42$ and 1.47 , respectively without significant difference among treatments.

Concerning the concentration of total lipids, the highest $(p<0.05)$ total lipids value was obtained with buffaloes fed silage rations (T2 and T3), while those fed control ration (T2) had the lowest value. These results indicated that using silage in the rations led to increasing levels of total lipids in the blood. Similar results were obtained by Gafaar (2001) who showed that the concentration of total lipids in plasma of Friesian calves fed rations contained different levels of concentrate mixture and corn silage significantly $(p<0.05)$ increased with increasing corn silage in the rations at 50 to $70 \%$ compared with those fed control ration (fresh berseem). No significant difference was found between lactating buffaloes fed T2 and T3. The differences in concentration of serum cholesterol between lactating buffaloes fed silage rations (T2 and T3) and those fed control rations (T1) were not significant. However, cholesterol levels tended to increase by 1.19 and $2.44 \%$ in the blood of buffaloes fed T2 and T3 compared to those fed T1. With this concept, serum cholesterol concentrations in this work were within the normal values reported for lactating buffaloes by Abdul, A. Amal (2001).

Concentration of thyroid hormones (triiodothyronine and thyroxin) of lactating buffaloes fed the experimental rations are summarized in Table (8) .The results indicated that the highest $(p<0.05)$ values of Triiodothyronine and thyroxin were obtained by buffaloes fed silage rations (T2 and T3) compared to those fed control ration (T1). Higher values of thyroid hormones in buffaloes fed silage rations may be due to higher TDN values of silage rations (T2 and T3) than control ration (T1) (Table 4). These results are in agreement with those obtained by Tiirats (1997). He reported that plasma thyroid hormones concentrations were affected by energy and dietary protein intake in Estonia dairy cows. Also, Ahmed (2003) indicated that the higher value of plasma thyroid hormones triiodothyronine and thyroxin concentration were recorded for lactating buffaloes fed high energy diets (120\% energy) than those fed $100 \%$ energy. In the present study levels of triiodothyronine (T3) and thyroxin (T4) in serum of Egyptian buffaloes are within the levels as described and reported by Farghaly (1992). 
Abd-EI-Moty, E. K. I. et al.

From the foregoing results, it could be concluded that preserving amount of maize and sorghum plants as silage can be successfully used for feeding ruminants without any adverse effect on productive performance and physiological responses. Therefore, offering facilities are need to make silage from fresh corn and sorghum plants to the farmers is very important and will help to apply this technology and encourage the farmers to use these products for feeding to reduce feed cost and save considerable of expensive concentrates specially in summer for lactating buffaloes under upper Egypt conditions.

\section{REFERENCES}

A.O.A.C. (1990). Official Methods of Analysis of Association of Official Analytical Chemists. $15^{\text {th }}$ Ed. Benjamin, Franklin Station, Washington, D.C.

Agriculture statistics. (2003). Summer and Nili crops, Economic Affairs Sector, volume 2. Ministry of Agriculture and Land Reclamation, Arab Republic of Egypt.

Ahmed. S.K.S. (2003). Studies on energy and protein allowances in ration for pregnant and milk producing buffaloes. Ph. D. Thesis, Fac. Agic., Ain Shams Univ., Egypt.

Abdul, A. M. Amal (2001). Some nutritional studies on Egyptian female buffalo cows fed green or dry feed and their effect on the productive performance and blood serum. M. Sc. Thesis, Fac. Agic., Ain Shams Univ., Egypt.

Bakr, A.A.L. (1995). Some studies on non-conventional feeds for ruminants. Ph. D Thesis Fac. Vet. Med. Zagazig Univ. Egypt.

Black, J.R., L.O. Ely, M.E. McCullough, and E.M. Sudweeks (1980). Effect of stage of maturity and silage additives upon the yield of gross and digestible energy in sorghum silage. J. Dairy Sci., 50:617.

Brandt, A. E. (1938) Test of Significance in Reversal or Switch-Back Trials. lowa Agr. Expt. Sta., Research Bull. 234. 1935.

Chauhan, T.R. (1995). Comparative performance of urea enriched maize/ maize Stover silage in growing buffaloes calves. Buffalo- journal 11:149.

Chopra. I.J.; D.H. Solomon and G.N. Beall. (1971). Radioimmunoassay for measurement of triidothyronine in human serum. J. Clin. Invest, 50, 2033.

Dhiman, T. R. and L. D. Satter. (1997). Yield response of dairy cows fed different proportions of alfalfa silage and corn silage. J. Dairy Sci.. 80, (9): 2069.

Dijk, H. J.; G.D. O'Dell and L.W. Grimes (1985). Lactation results from dairy cows fed corn, sorghum or wheat silage in complete ration. J. Dairy Sci., 68 (Suppl. 1) 266 (Abst).

Doumas, B.T. (1971). Automated analysis. Bochringer Mannheim Clin. Acta.31-87. 
Duncan, D.B., (1955). Multiple range and Multiple F- test . Biometrics, 11:142.

El-Aidy, A.A.A. (2003). Effect of feeding maize silage usage with berseem on the production and reproductive performance of dairy buffaloes. M. Sc. Thesis, Fac. Agic., Ain Shams Univ., Egypt.

El-Ashry, M.A.; Abou-Selim, I.A.; El-Sayed, H.M. and A.A. El-Aidy (2003). Effect of maize silage with berseem on the productive performance of dairy buffaloes. Egyptian J. nutrition and feeds 6 (1):25.

Elready, K.F.A. (2000). Effect of dietary silage on dairy cattle performance. M. Sci. Thesis, Fac. of Agic., Menoufiya Univ., Egypt.

El-Sayes, M.F.; M.R.M. Mostafa and M.K. Hathout (1997). Nutritional and economic efficiency for using the maize silage in fattening buffalo calves locally. $5^{\text {th }}$ World Buffalo Congress, Animal Prod. Res. Ins. A.R.C. pp 386, Giza, Egypt .

Farghaly. H.A.M. (1992). Studies on the relationship between thyroid hormones, ovarian hormones, $\mathrm{GnRH}$ and reproductive performance of Egyptian buffaloes. Ph.D. Thesis, Fac. of Agic., Cairo Univ., Egypt.

Gafaar, H.M.A. (2001). Performance of growing calves fed rations containing corn silage. Ph. D. Thesis, Fac. of Agic., Kafr El- Sheikh, Tanta Univ., Egypt.

Glen, A.B. (1985). Alfalfa silage or hay versus corn silage as a sole forage. J. Dairy Sci., 68: 3262.

Graf, C.M.; M. Kreuzer and F. Dohme (2005). Effects of supplemental hay and corn silage versus full-time grazing on ruminal $\mathrm{pH}$ and chewing activity of dairy cows. J. Dairy Sci. 88:711.

Irvin, W.J. and R.M. Standever (1968). Serum triidothyronine uptake musing coated charcoal in the assessment of thyroid function, J. Endocrinal. $41 ; 31$.

Kaplan, A. and J., Szalbo (1983). Clinical chemistry: interpretation and techniques. $2^{\text {nd }}$ ed. p157.

Khinizy, A.E.M.; R.T. Fowad; M.M. Mohy El-Deen; Badr, B. Matter and A.A.M. Fahmy (1997). Effect of feeding whole green maize silage with urea molasses minerals mixture on performance of buffalo calves. Egypt J. Appl. Sci. 12 (8):408.

Kumar, N.; Snigh, U.B. and Verma, D.N. (1980). Effect of different level of dietary protein and energy on growth of mal buffalo calves. Indian. J. Anim. Sci., 51:513.

Lopez-Guisa, J.M.; L.D. Satter and M. Panciera. (1991). Utilization of ensiled corn crop residues by Holstein heifers. J. Dairy Sci., 74: 3160.

Lucas, H.L. (1956). Switch back trials for more than tow treatments. J. Dairy Sci., 39: 146.

Mahmoud, A.M.; M.M. Bendary; M.A. Harfoush and G.A. Ramadan (1992). Effect of feeding lactating cows corn silage on milk production compared with traditional summer and winter ration. J. Agric. Sci. Mansoura Univ. 17(19):2904. 
Mohamed, A.H.; A.I. Gomaa and M.M. Mohamed (1998). Utilization of corn stover silage or whole corn plant silage in lactation buffaloes rations. J. Agric., Mansoura Univ., 23 (7):3081.

Mohamed, M.M. Sayeda M.M. Ahmed and Bendary , M.M. (1999). Productive and reproductive performance of growing calves fed rations containing maize silage Egypt. J. Nut. and Feeds (2) 445.

NRC. (1988). National Research Council. Nutrient requirement of dairy cattle. $6^{\text {th }}$ ed., National Academy of science, Washington, D.C.

Nichols, S. W.; M. A. Froetschel; H. E. Amos and I. O. Ely (1998). Effects of fiber from tropical corn and forage sorghum silages on intake, digestion, and performance of lactating dairy cows. J. Dairy Sci., $81: 2383$.

Perry, T.W. and M.J. Cecava (1995). Beef cattle feeding and nutrition. $2^{\text {nd }}$ ed., Academic Press, Inc., U.S.A.

Raafat, N.A. and M.S. Saleh (1962). Two formulas for conversion of cow's and buffalo's milk different fat percentages into milk of standard fat percentage, proceeding of $1^{\text {st }}$ Anim. Prod. Conference at Minia: 203.

SAS (1996). SAS User's Guide, Statistics $\left(6.2^{\text {th }}\right.$ Ed) Cary N.C: SAS Institute Inc.

Schalm, O.W., N.C. Jain and E.J. Corroll (1975). "Veterinary Hematology". $3^{\text {rd }}$ Ed., Lea \& Febiger, Philadelphia, USA. .

Thomas, C.; B.G. Gibbs and J.C. Tayler (1981). Beef production from silage. 2- The performance of beef cattle given silage of either perennial ryegrass or red clover. Anim. Prod. 32: 149.

Tiirats, T. (1997). Thyroxin, triidothyronine and reserve triidothyronine concentration blood plasma in relation to lactation stage, milk yield energy and dietary intake in Estonia dairy cows. Acta. Vet Second 38:339.

Trinder, P. (1969). Test-composition, enzymatic determination of glucose. Ann. Clin. Biochem, 6:24.

Valdez, F.R.; J.H. Harrison and S.C. Fransen. (1988). Effect of feeding cornsunflowers silage on milk production, milk composition, and rumen fermentation of lactating dairy cows. J. Dairy Sc. 71: 2462.

Van Keulen, J. and B.A. Young (1977). Evaluation of acid insoluble ash as neutral marker in ruminant digestibility studies. J. Anim. Sci., 44:2982. 


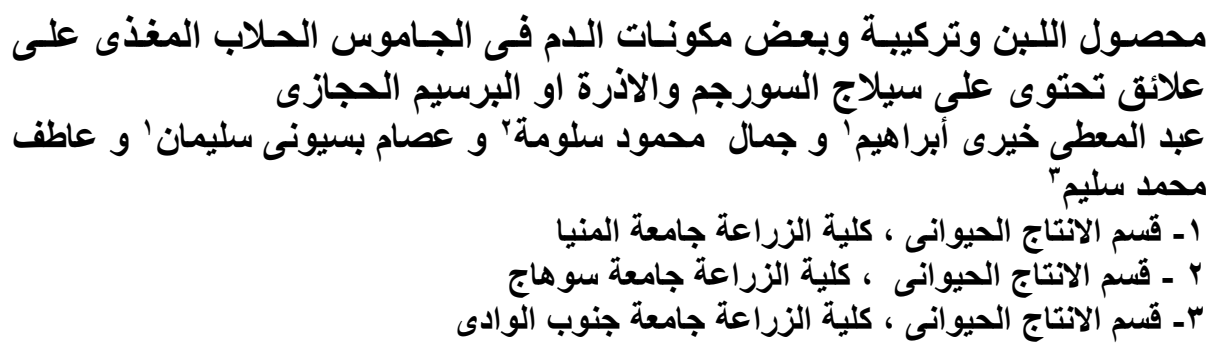

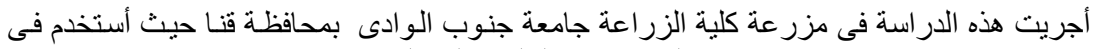

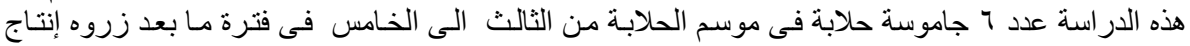

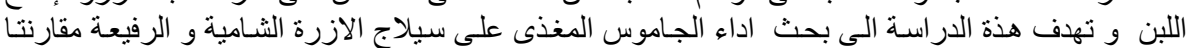

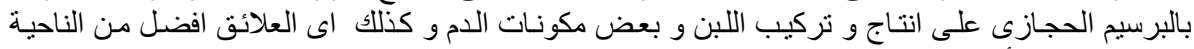

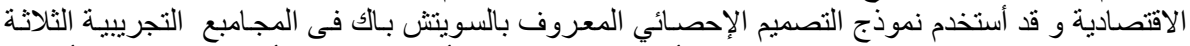

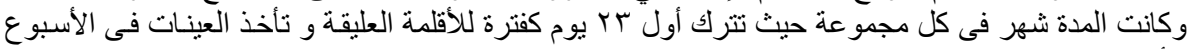

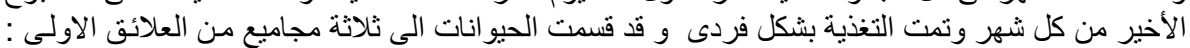

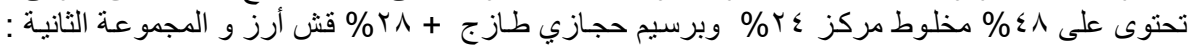

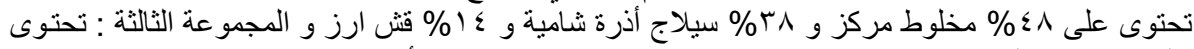

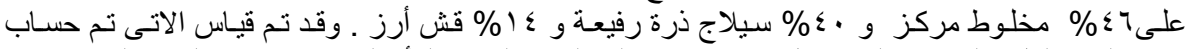

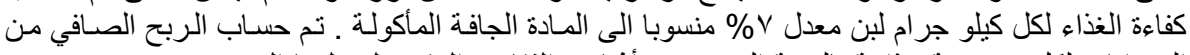

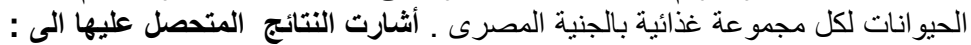

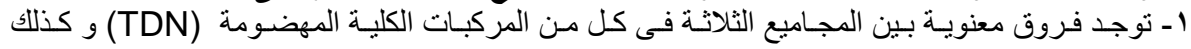

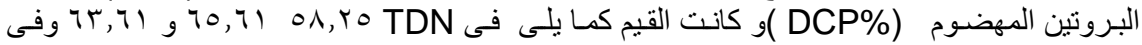
V DCP

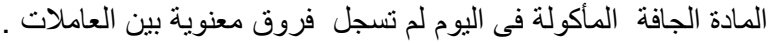

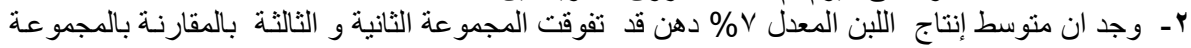

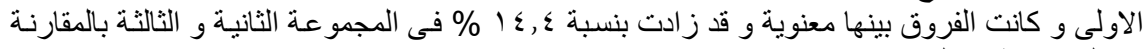

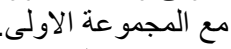

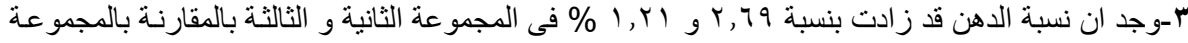

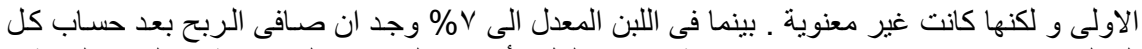

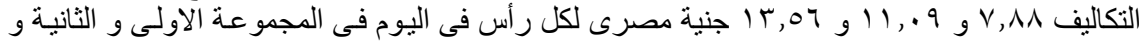

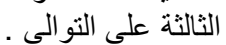

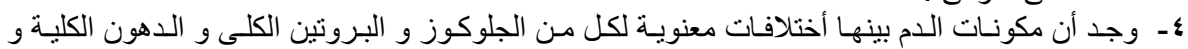

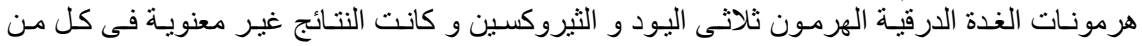

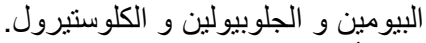

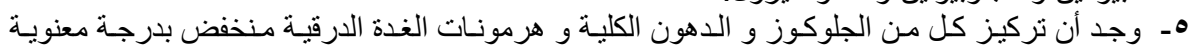

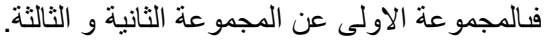

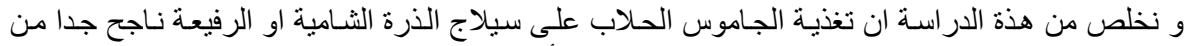

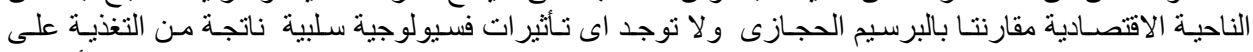

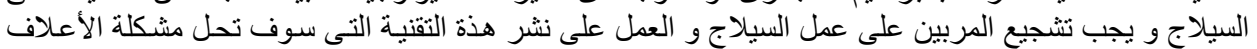
الخضر اء فى الصيف وخصوصا تحت ظروف صلئ صعيد مصر. 